\title{
THREE-TIER ARCHITECTURE FOR INTERNET OF THINGS NETWORKS
}

\author{
Globa L.S., Kurdecha V.V., Shoferivskyi A.S. \\ The National Technical University of Ukraine "Igor Sikorsky Kyiv Polytechnic Institute" \\ Kyiv, Ukraine
}

Background. There is a large number of devices used on Industrial objects and all these devices should interact. Such usage of IoT in the corporate environment or in industrial facilities is called IIoT (Industrial IoT). According to statistical data of the information portal "Statista", there is a problem of a rapid increase in the number of devices nowadays. Therefore, it is necessary to create networks that can withstand all connected devices. The relevance of the paper is determined by the need to connect a large number of devices in a small area in the Industrial Internet of Things.

Objective. The aim of the paper is to find the way to increase the number of IoT-devices per unit area through 3-lvl IoT architecture and the way to modify the interaction between IoT nodes.

Methods. Analysis of publications devoted to the Internet architecture. Analysis of ways to increase the number of serviced nodes per unit area. On the basis of the analysis, a modification aimed at increasing the number of served IoT-nodes is proposed.

Results. The three-level IoT architecture and an appropriate way of interaction between IoT devices are proposed. The circuit of three-tier architecture was developed and graphically displayed, the main feature of which is the existence of an additional node, which allows connecting a larger number of end devices. Algorithms and functions of the devices at all levels of three-tier architecture were described in detail. The model of the monitoring system and the advantages of its usage in the three-tier architecture are described. Also the effectiveness of the proposed method compared to the existing ones was mathematically proved.

Conclusions. The three-level architecture of the IoT network has been developed, which is characterized by the availability of an additional level of the router, which allowed concentration of the group of end nodes in the router and unload the gateway. This allowed increasing the maximum number of terminal devices.

Keywords: Industrial Internet of Things; IIoT; IoT gateway; Three-tier architecture; Internet of Things; The way of interaction between IoT nodes.

\section{Introduction}

The popularity of Internet technology keeps increasing nowadays. Intelligent devices have been used in industry for a long time. But not so long ago, all these systems began to connect to the Internet or to reconfigure existing networks so that they could be managed not only locally, but also from any corner of the world.

According to statistical data of the "Statista" information portal, more than 20 billion devices are already connected to the Internet, and according to its forecasts the number of such devices will already be over 50 billion in 5 years [1]. Therefore, it is very important to create systems that can withstand the connection of a large number of devices.

Industrial objects use a large number of devices and all these devices should interact between each other. Such use of IoT in the corporate environment or in industrial facilities is called IIoT (Industrial IoT Industrial IoT) [2]. Basically, this is the same IoT, but the number of devices used in such networks is quite large, that is why they are issued as a separate subspecies.

There is an issue of a rapid increase of the number of IIoT devices, so it is necessary to create such kind of networks that can withstand all connected devices. Nowadays, the problem of a steep increase of the number of devices may be solved in several ways:

- connecting each sensor to the Internet independently (it is not widely used because of the transport networks reloading)

- creation of each user PAN (Personal Area Network), that is often used with many devices connected [3].

Such personal network of IoT devices will interact in a particular area and by connecting to the Internet, it will also be able to interact with other, similar, systems.

\section{Overview of existing interaction architectures}

Creation of a PAN for IIoT may use the sensor networks: ad-hoc networks, but they often work for data transmission only and can't receive commands from the 
server, so they are more suitable not for industrial objects, but for open space usage.

Another option is to use gateways in order to interact with IoT devices (using a two-tier interaction architecture). These gateways connect IoT devices and transfer data over the Internet through a gateway.

Two-tier architecture is the most popular way of deploying IoT networks. In this architecture, all devices are connected to the Internet (data processing server) through a special device - a gateway (Fig. 1).

The number of such devices can reach several hundreds (it depends on the way of how the information is transmitted). With such an architecture, each IoT device has all the necessary sensors, or certain control equipment, it reads data from its sensors: analog or digital and makes elementary preprocessing of this data so that all the data has a similar (identical) look.

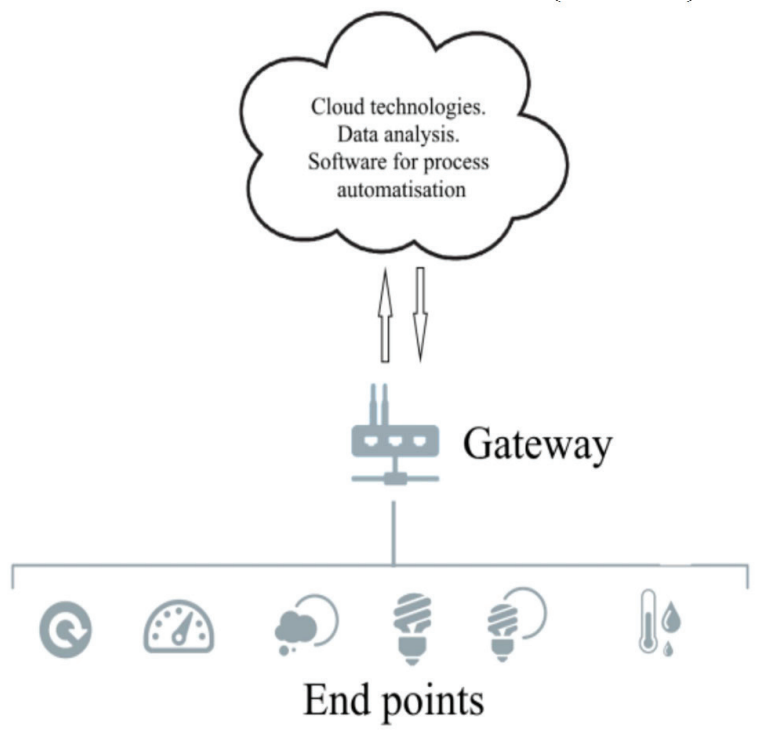

Fig. 1 Two-tier architecture of the IoT network

The corresponding gateway accepts all data from various IoT devices, perform their pre-processing, sends them to the Internet, and then sends commands to the devices that come from the server.

The gateway is the most important element in the architecture that connects end nodes and transmits the data that was read from the sensors. It also performs the data preparation so that it can be transmitted over the Internet to the server (to a format suitable for a particular communication protocol). Usually, gateways are microcomputers that have their own operating system with user interfaces like a graphical interface or a regular console. It's also possible to connect remotely to this device and reconfigure it, reprogram or remotely manage the entire subnet.

The advantages of such architecture are the following:

- The ability to connect a bunch of devices;
- the possibility of local devices interconnection without connecting to the Internet;

- lower cost per device.

- ensuring secure data transmission.

- less probability of data loss.

- integration into the network heterogeneous devices.

- network scalability.

The drawbacks of such architecture are the following:

- Impossibility of connecting several hundreds of devices to one gateway;

- difficult integration of existing devices with a new architecture;

- larger architectural costs;

- data retention delay.

Such a solution is suitable for some smart home systems or for not large rooms, but with an increase of the number of devices, it has its own limitations and when reaching a certain limit, it is necessary to increase the number of such gateways. Furthermore, when talking about IIoT, it is needed to consider the possibility of connecting more than a very large number of sensors (more than a thousand). Taking to the account that the cost of such devices is not low, this paper shows the possibility of usage the modified method of IoT devices interaction, based on two-tier architecture, but with the addition of an intermediate device - three-tier architecture

\section{Three-tier architecture}

The solution proposed in this paper is the use of architecture with an ability to connect a large number of devices by using only one gateway (Fig. 2). This is accomplished by using additional intermediate devices "routers" instead of multiple gateways. Such an approach is called the three-tier communication architecture of IoT devices [7].

When using this architecture, all end devices transmit their data not to the gateway at once, but to the intermediate level -router. The mentioned nodes unite around their router and form certain cells (Fig. 3), where they operate independently, transmit data to the router and do not interfere with devices from other cells. Therefore, different routers can operate on the same frequencies and communication channels as the neighboring routers. Variating the sizes and parameters of these cells, the maximum number of devices in a certain area can be changed as well.

This intermediate link in the system is very important, since the presence of these devices allows you to concentrate the load coming from terminal devices, group the data from the latter and send them to the router. Not more than a dozen routers are connected to the gateway at a time, and to each of them may be 
connected dozens or even hundreds of end nodes. Thus, the network can maintain such connections without overload.

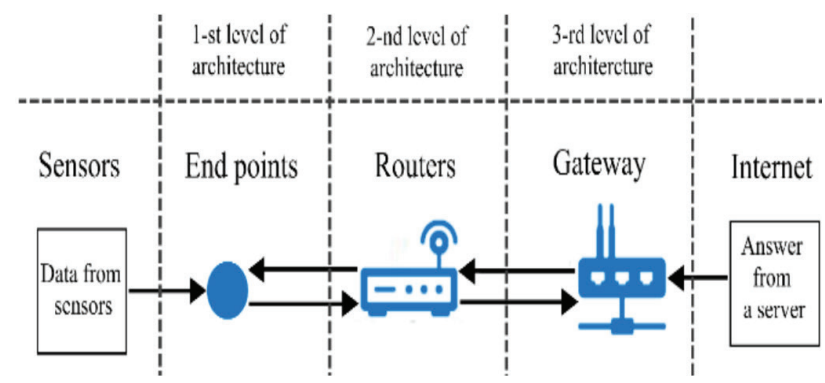

Fig. 2 Interaction in three-tier architecture

Routers are an important link in the three-tier architecture, however they can't work for a long time autonomously; therefore, such devices should have some kind of uninterruptible power supply or should be permanently recharged, since such devices must keep in touch with the gateway and, at the same time, receive data from end nodes losslessly. That is why, such devices as routers rarely use sleep mode. This, of course, can be considered as the shortcomings of such a system, but for the industrial Internet of Things this is not an issue as usually there are no problems with the power supply.

The principle of building a network with a three-tier interaction method is very similar with one that is used for two-tier interaction, but there are routers used instead of gateways, which makes the entire system muchcheaper. There is no significant rise in price when using the presented method because the more concentration of devices in a certain area, the more intermediate level devices are used, but they are much cheaper than the gateways.

According to this kind of interaction, when reducing the cell size on an unchanging area, the maximum number of operating devices in this cell remains unchanged, so the concentration of devices per unit area increases, what makes it possible to increase the number of such cells (routers) in a certain area. Due to this, the total number of end nodes in the specified area will increase significantly, directly proportional to the number of cells used in the given system.

It should be noted that as the number of levels of data transmission increases, the delay and data transmission speed will also increase, because the traffic generated by the end sensors, unlike the two-tier architecture, passes through an intermediate level, which also creates the delays when sending information and each router may have some bandwidth limitation, so the maximum speed of each device, due to this, may also be limited.

An important factor is the bandwidth of the gateway itself. If the speed of access to the Internet is not high enough, then the maximum speed of all end devices also decreases, so when calculating the network, the following factor should be considered: when using a large number of end nodes, you need to have stable and fast access to the Internet. Although since the gateway in this architecture is only one, it is often provided with a fairly stable transmission channel (for example, a wired connection).

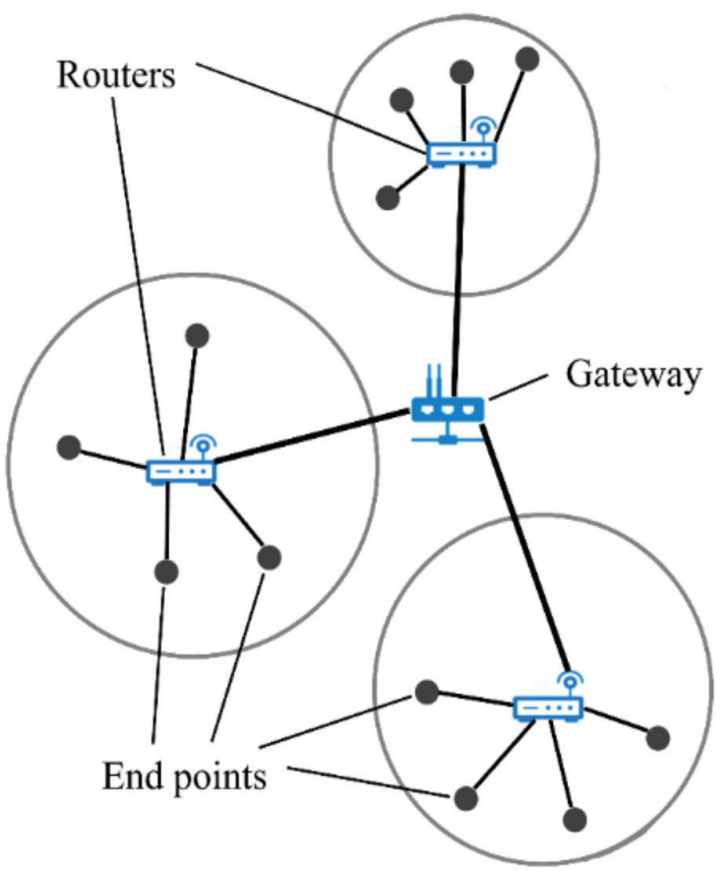

Fig. 3 Schematic mapping of three-tier architecture

In this method of interaction, the role of end nodes and the gateway remain the same, but since the sensors are close to intermediate levels, it is possible to apply radio modules with good energy efficiency indicators. Transmission protocols for IoT nodes are: ZigBee, BLE, LoRa, and others. Also, such devices can work with Wi$\mathrm{Fi}$, but the use of this technology is not entirely appropriate in this architecture.

End devices can be made as simple as possible, because all the hard work is supposed to be performed at higher levels. This allows reducing their cost, complexity of design and allows them to work autonomously for up to 3 years without additional power and recharging their battery. The duration of the continuous operation depends, of course, on the task performed by the device and the battery capacity. The possibility of such a long battery life is due to the fact that the end devices are allocated a minimum of tasks and therefore they can perform them effectively and then enter a standby or sleep mode, if so provided in this device. 
As the second level of the architecture presented, the router acts as a router. Such devices can be several dozen. These devices act as an intermediate link in the system, but they are important because the presence of these devices allows you to concentrate the load that comes from the end devices, group the data from the latter and send them to the router. It is the use of routers to connect and manage hundreds of devices using only 1 Gateway. This is due to the fact that no more than a dozen routers are connected to the gateway at the same time and thus can maintain such connections without overload.

Role of routers:

- receive data from terminal devices;

- group data from multiple nodes;

- send all collected data to the gateway;

- receive data from the gateway;

- send replies to commands on end devices.

Routers are an important link in the three-tier architecture, but they can not work for a long time autonomously; therefore, such devices should mainly have some kind of uninterruptible power supply or be permanently recharged, since such devices must keep in touch with the gateway and, at the same time, take, lossless, data from end nodes. Because of this, devices such as routers rarely use sleep mode.

The communication between the router and the gateway can be the same as for connection to end nodes, but the focus is on such parameters as: good transmission rates, high bandwidth, depending on what parameters are needed on the system. Ethernet or other wired options can also be used to transfer data between the gateway and routers, but in this case it's hard to call such a system as a wireless one.

As it was already mentioned, the best practice for industrial use of IoT is to connect the gateway to the wired connection, but other options are also possible, for example, in order to either distribute traffic between different devices or to implement a backup link to the Internet. The most popular ways to connect to the Internet for such solutions are $2 \mathrm{G}, 3 \mathrm{G}$ and $4 \mathrm{G}$ (LTE) and WIFI technologies. Due to the fact that WIFI access points are the most widespread ones, they are often used by the gateway for data transmission.

The gateway is only one for the entire three-tier architecture, but due to adding another device, it is possible to improve the system's fault tolerance. Therefore, if the high fault tolerance is required, it is needed either to make a system with a quick replacement of the non-working gateway, or to split all connected devices between two independent gateways.

Tasks that the gateway performs:

- receive data from all connected routers;

- pre-processing this data;
- provide a reliable and secure way of data transmission;

- locally store data;

- conduct preliminary analysis of data;

- send data and all information to the server;

- receive commands and information from the server;

- send commands to the required routers.

Since geteway manages the whole network, it is also possible to conduct a preliminary analysis of data and to send it along with some certain results of analysis to the server, or even automatically give commands to other nodes: to perform a small function of a local server.

If it is needed to rearrange two-tier architecture in three-tier one, there is no point in changing the entire network, but simply to reconfigure the end nodes so that they send / receive information not from the gateway, but from the router and also to reconfigure the gateway so that it can process the data from the intermediate links (often it receives not only the data from sensors, but grouped data from the previous level).

\section{M2M connection in proposed architecture}

To maximize network performance and to efficiently use existing system resources, it's need:

- the ability to change some system parameters: change the frequency of sending data from a particular device, or from a group of devices that are connected around a particular router;

- the ability to switch the device to another router; this makes it possible to rebalance the network;

- the ability to programmatically notify the router, whether to connect a new device to the system, or to exclude a particular device from the system;

- automatic balancing of the network to balance the load that comes to different segments of the network;

- Prioritizing the operation of devices, for the possibility of rapid response to data from priority devices;

- the ability to change the destination of the end node (change the type of sensor), if the specified device, there are such sensors.

To implement the network capabilities described above, devices in the system must implement a certain set of APIs that can be called from higher levels, thereby changing the work of either specific elements of the network or the entire system segment.

Commands that need to be implemented on devices.

On terminal devices:

- Frequency update of data;

- displaying the priority of the work of the terminal devices;

- Between the necessary sensors on the device (if there are more than one); 
- the ability to switch the device to another router (if available) for this device;

- send information about the status of all internal parameters of the item.

On routers:

- Switching devices, turning on or off end nodes from their subnet;

- implement the priority of the devices, based on their priority parity;

- the ability to set the frequency of sending data to all of its endpoint subnets.

- Get commands about moving the device to the subnet of another router;

- send information about the status of all internal parameters of the item.

On the gateways:

- Network rebalancing;

- Collecting data about the parameters of all devices and routers;

- Sending a team about rebalancing the network;

- analysis of the parameters of all elements of the network.

Effective use of all system resources should be able to call, in a certain way and under certain conditions, the AIA described above. To save all parameters of the network elements and structure of the system, the use of the special configuration file is proposed. This file will describe the entire hierarchical structure of the network. For this, the JSON format is the best. It is quite simple to fill (even manually), and does not contain any extra characters (like XML), so that such a file will have less disk space, and less time will be required for its betrayal over the network.

The specified file describes the complete structure of the network: Connected end devices, routers, and interconnections between all devices. Also, the file contains all technical data that is required for network operation, device identification and monitoring of the state of these devices.

The configuration file has a hierarchical structure with three similar entities that correspond to a certain level of architecture: gateway, routers, nodes. Each of these entities has a set of similar parameters.

\section{Comparison of architectures}

In the two-tier architecture, the limitation of the number of connected devices at the same time is related to the radio modules limits or communication devices themselves, the number of gateways used in the system, etc. The general formula for calculating the number of devices looks like:

$$
N_{\text {Mpuc }}=\sum_{i}^{l} \sum_{j}^{m} N_{i j}
$$

Nij - the number of devices on the $\mathrm{j}$-th communication module, the i-th gateway;

$l$ - the number of gateways in the system;

$m$ - the number of communication modules.

As it is stated above, the same communication modules with the same architecture are used, so for calculating the maximum number of devices it can be assumed that all communication modules have the same, the maximum for a certain technology, the number of devices. Then formula (1) can be simplified, and written in the following form:

$$
N_{M A X}=l \cdot m \cdot N \text {, }
$$

where

$N$ - number of devices per communication module.

In the three-tier architecture an additional device (the router) is used, so the formula for calculating the number of connected devices will look different, relatively twotier architecture:

$$
N_{\text {Mpuc }}=\sum_{i}^{l} \sum_{j}^{m} \sum_{i}^{n} N_{i j k}
$$

where

Nijk- the number of end nodes on the k-th communication module of the $\mathrm{j}$-th router, the $\mathrm{i}$-th gateway;

Taking into account all restrictions, formula (3), will take the form:

$$
N_{M A X}=n \cdot m \cdot l \cdot N
$$

where

$l$ - number of gateways.

$n$ - number of routers;

$m$ - the number of modules on a particular router.

To calculate the maximum number of devices located on a certain area in a three-tier system, we can reduce the power of the BLE transmitter module so that its radius of transmission does not exceed $5 \mathrm{~m}$. Thus, different cells (Fig. 4) are created, so to speak, for each router in the system. Therefore, it is possible to increase the number of devices in the represented architecture because of the use of such cells.

According to Fig. 4, when using 1 router, the system degenerates into a two-tier architecture, and there the number of devices will always be the same, regardless of whether the range of action of the communication module will increase or decrease, because all these devices occupy all free channels of data transmission. In the three-tier architecture, the range of communication modules on the end devices decreases and they create a certain cell around the router to which they are connected. Therefore, with the increase in the number of these routers, the area at which the devices may be located increases as well.

where 
According to the graph Fig. 5, a three-tier mode of interaction of IoT nodes can support more devices under equal conditions in a limited amount of space.

As can be seen from Fig. 5, in a two-tier architecture, the number of devices will always be the same, regardless of whether the range of the communication module action will increase or decrease, because all these devices occupy all free data transmission channels. In the three-level architecture, the range of communication modules on the end devices decreases and they create a certain cell around the router to which they are connected, therefore, with the number of these routersincreasing the expected area of the devices location increasing too.

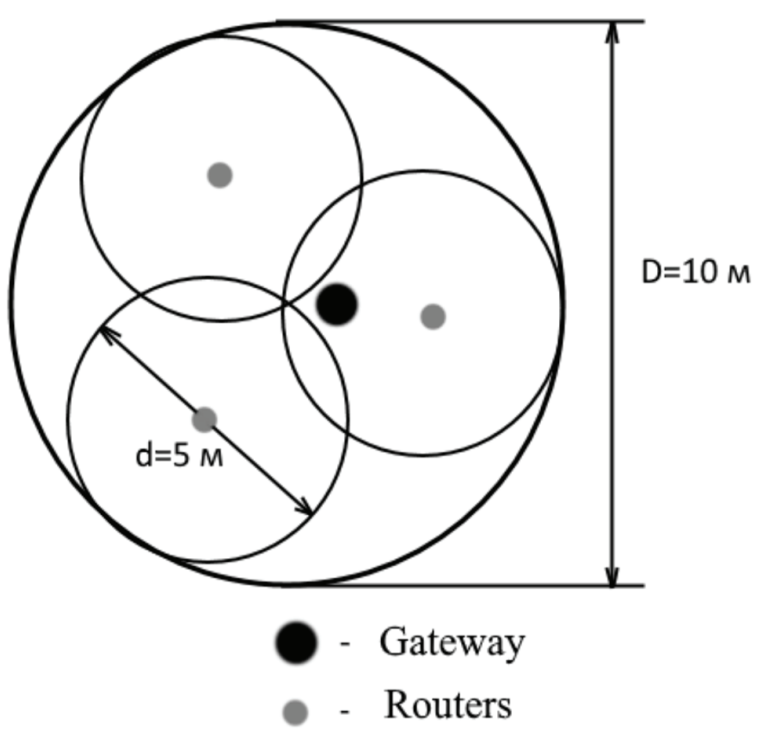

Fig. 4 Location of routers in three-tier architecture

For three-tier architecture maximum number of the nodes was placed in defined area.

So, the routers should be placed in such way that as much as possible evenly covered the entire space of the room.

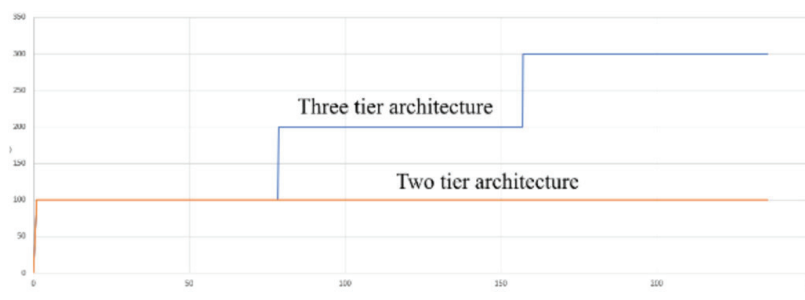

Fig. 5 Comparison of two-tier and three-tier architectures

To calculate the maximum number of devices that are located on a certain area in a three-tier system, we will routers so that they cover as much as possible the entire space of the room. This creates, different cells (Fig. 4) for each router in the system. And due to the use of such cells, it is possible to increase the number of devices in the presented architecture

For calculations we take the formula for two-tier architecture and in analogy with the three-level architecture, the formula is simpler, for the maximum load on the network:

$$
\mathrm{N}_{\mathrm{r}}^{\text {gate } 3 \mathrm{x}}=\mathrm{n}_{\text {route }} \cdot \mathrm{n}_{\text {nodes. }} \mathrm{N}_{\mathrm{r}}^{\text {nodes. }}
$$

Since the number of devices that we can connect to 1 communication module is known from the two-level architecture, we can take this value also for the threelevel, because the way of communicating with the router and the gateway (two-tier architecture) with the end devices, identical.

So, $\mathrm{N}_{\mathrm{r}}^{\text {nodes }}=80$ nodes. Also the bandwidth of the module of communication with the terminal device, we are aware of: 20 (Mbits/s).

$$
\begin{gathered}
\mathrm{n}_{\text {nodes. }}=6 \\
\mathrm{~N}_{\mathrm{p}}^{\text {gates 3x }}==3 \cdot 6 \cdot 80=1440 \text { nodes }
\end{gathered}
$$

With an increase in the number of connected communication modules, to the gateway or routers, at a constant transmission rate, it is clear that the three-level architecture reaches its maximum after connecting 6 communication modules to each router (Fig.6).

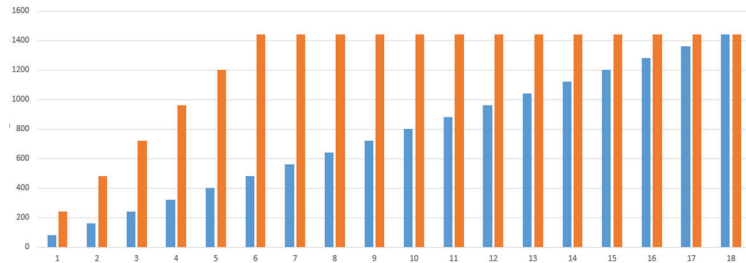

Fig. 6 Dependence of the number of terminal devices on the number of modules of communication

Blue- 2- tier arch., red -3-tier architecture

It is important to note that in the above calculations, the bandwidth of the communication modules was taken into account with a certain stock, but this situation can be improved in the three-tier architecture, in this paper a stock factor of 0.8 was taken, which means that up to $20 \%$ of the bandwidth is not used of course, in reality, this value is smaller, but at all times we have a certain spare stock. For the rational use of the described stock, you can use the described monitoring system with the implementation of automatic network balancing algorithm.

To determine the number of devices per unit area, consider the dependence of the area on which the devices are located, on the number of routers. Since the radius of each router communication module is $5 \mathrm{~m}$, the area covered by each router will be $S=\pi \times r^{2}$, where $r$ - radius of the router communication module. 
$S=78.54 \mathrm{~m}^{2}$

Construct a table of dependence of the number of devices on the number of routers (cells) - tabl.1.

Assuming that the cells do not intersect, then the direct dependence, the number of devices from the square, and the number of devices will intersect, then the area of the sensors will be reduced and due to the interference of the sensors to each other, their number will also decrease. For these reasons, it can be concluded that the dependence is directly proportional, except in the case of only 1 router.

Table 1

Dependence of the devices number from the routers number

\begin{tabular}{|c|c|c|}
\hline $\begin{array}{l}\text { Number of } \\
\text { Routers, } p c s .\end{array}$ & $\begin{array}{l}\text { Device } \\
\text { placement area, } \\
m^{2}\end{array}$ & $\begin{array}{l}\text { Number of } \\
\text { connected } \\
\text { devices, } p \text { cs. }\end{array}$ \\
\hline 0 & 0 & 0 \\
\hline 1 & 78.54 & 480 \\
\hline 2 & 157.08 & 960 \\
\hline 3 & 235.62 & 1440 \\
\hline 4 & 314.16 & 1920 \\
\hline 5 & 392.7 & 2400 \\
\hline 6 & 471.24 & 2880 \\
\hline
\end{tabular}

In a two-tier architecture, the number of devices will always be the same, regardless of whether the range of action of the communication module will increase or decrease, because all these devices occupy all free data transmission channels. And in the three-level architecture, the range of communication modules on the end devices decreases and they create a certain cell around the router to which they are connected, therefore, with the increase in the number of these routers, the area at which the devices may be located increases.

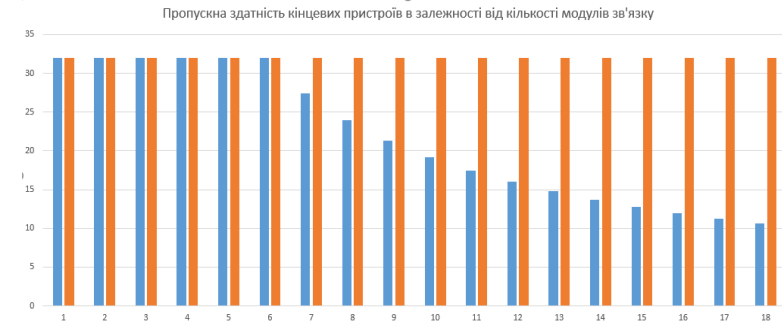

Fig. 7 Dependence of end-device bandwidth on the number of connected communication modules

Blue- 2-tier arch., red -3-tier architecture

The bandwidth of all devices in different ways of interaction will depend on the maximum transmission speed of the communication module of each device and the transmission speed of the intermediate nodes. In a two-tier architecture, with a strong blurring of the number of connected modules (and hence of devices), there will be no reduction in bandwidth, because all modules will be connected directly to the gateway, and its bandwidth is quite large.

In the three-level architecture, with the increase of modules on the router (when the wifi bandwidth is not enough to handle all devices), the maximum speed of the end devices begins to decrease (Fig. 7).

\section{Conclusions}

With the current pace of IIoT technologies development, the number of IoT devices keeps increasing, so it is necessary to have systems that can withstand a large number of connected devices in a small area of space.

In this paper, existing methods of interaction of IIoT nodes were considered, their description and comparison were made. It is needed to create PAN network if the connection of a very large number of devices is required. Therefore, in this paper, the use of three-tier architecture was proposed, which is a modification of two-tier architecture, with the addition of the intermediate level the router. The router acts as an intermediate link and collects data from several dozens of sensors and thus reduces the number of connections to the gateway.

A three-tier interaction method uses the benefits of a two-tier, but it allows connecting a much larger number of devices. It is allowed at the expense of a small increase in the delay and decrease the bandwidth of one IoT node, but the transmission rate in the three-tier architecture is still enough, because each IoT node does not generate very large amount of data. The paper also presents a comparison of the above-mentioned methods of interaction and graphically depicts the advantages of a three-tier architecture.

\section{References}

[1] Internet of Things (IoT) connected devices installed base worldwide from 2015 to 2025 (in billions). https://www.statista.com/statistics/471264/iot-number-ofconnected-devices-worldwide. (access date: 01.12.2017).

[2] What is the Industrial Internet of Things? https://www.iscoop.eu/internet-of-things-guide/industrial-internetthings-iiot-saving-costs-innovation/industrial-internetthings-iiot (access date: 03.12.2017).

[3] Rouse M. Personal area network (PAN). http://searchmobilecomputing.techtarget.com/definition/p ersonal-area-network (access date: 28.03.2016).

[4] Internet of Things: Wireless Sensor Networks. http://www.iec.ch/whitepaper/pdf/iecWPinternetofthings- LR-en.pdf (access date: 26.11.2017).

[5] Zhong C. Study on the IoT Architecture and Gateway Technology. / C. Zhong, F. Univ, Z. Zhu, R. Huang // 14th International Symposium on Distributed Computing and Applications for Business Engineering and Science. Guiyang, 2015 p. 196-199. 
Глоба Л.С., Курдеча В.В., Шоферівський А.С.

Трирівнева архтектура для мережі Інтернету Речей

Проблематика. На промислових об'єктах використовується велика кількість пристроїв і з усіма цими пристроями необхідно взаємодіяти. Використання ІоТ в корпоративному середовищі або на промислових об'єктах має назву IIоT (IndustrialIoT - Промисловий IoT). Згідно статистичних даних інформаційного порталу "Statista" на сьогодні спостерігається проблема стрімкого збільшення кількості пристроїв. Актуальність роботи визначається необхідністю підключення великої кількості пристроїв на невеликій площі в Промисловому IоT.

Мета досліджень. Підвищення кількості обслуговуваних ІоТ-вузлів на одиницю площі через запропоновану трирівневу архітектуру та модифікацію способу міжмашинного зв'язку

Методика реалізації. Аналіз публікацій, присвячених архітектурі Інтернету Речей, способів збільшення кількості обслуговуваних вузлів на одиницю площі. На основі аналізу запропоновано модифікацію, що спрямована на підвищення кількості обслуговуваних ІоТ-вузлів.

Результатидосліджень. Запропоновано трирівневу архітектуру ІоТ та відповідний ій спосіб взаємодії пристроїв ІоТ. Розроблено схему трирівневої архітектури, головною особливістю якої є наявність проміжного вузла, який дає можливість підключати більшу кількість кінцевих пристроїв. Описано алгоритми та функції пристроїв на всіх рівнях трирівневої архітектури. Проведено математичну оцінку запропонованого рішення порівняно з існуючими.

Висновки. Розроблено трирівневу архітектуру ІоТ мережі, яка відрізняється наявністю додаткового рівня маршрутизатора, що дозволило сконцентрувати навантаження групи кінцевих вузлів в маршрутизаторі та розвантажити шлюз.Це дозволило підвищити максимальну кількість кінцевих пристроїв.

Ключові слова: Промисловий Інтернет речей; IIоT; IоT шлюз; Трирівнева архітектура; Інтернет речей; Спосіб взаємодії ІоТ вузлів.

\section{Глоба Л.С., Курдеча В.В., Шоферивский А.С.}

\section{Трехуровневая архтектура для сети Интернета Вещей}

Проблематика. На промышленных объектах используетс ябольшое количество устройств и со всеми этими устройствами не обходимо взаимодействовать. Использование Интернета Вещей в корпоративной бреде или на промышленных объектах называется Промышленным Интернетом Вещей (Industrial IoT). Согласно статистическим данням ин ормационного портала "Statista" сегодня наблюдается проблема стремительного увеличения количества устройств. Актуальность работы определяется необходимостью подключения більшого количества устройств на небольшой площади в Промышленном Интернете Вещей.

Цель исследований. Повышение количества обслуживаемых узлов Интернета Вещей на единицу площади с помощью предложенной трехуровневой архитектуры и модификацию способа межмашинной связи.

Методика реализации. Анализ публикаций, посвященных архитектуре Интернета Вещей, способов увеличения количества обслуживаемых узлов на единицу площади. На основе анализа предложено модификацию, которая направлена на повышение количества обслуживаемых узлов Интернета Вещей.

Результаты исследований. Предложено трехуровневую архитектуру ИВ и соответствующий ей способ взаимодействия устройств ИВ. Разработано схему трехуровневой архитектуры, главной особенностью которой является наличие промежуточного узла, который дает возможность подключать большее количество конечных устройств. Описаны алгоритмы и функции устройств на всех уровнях трехуровневой архитектуры. Проведена математическая оценка предложенного решения по сравнению с существующими.

Выводы. Разработана трехуровневая архитектура сети Интернета Вещей, которая отличается наличием дополнительного уровня маршрутизаторов, что позволило сконцентрировать нагрузку группы конечных узлов в маршрутизаторах и разгрузить шлюз. Это позволило повысить максимальное количество конечных устройств.

Ключевые слова: Промышленный интернет вещей; ІІоТ; ІоТ шлюз; трехуровневая архитектура; Интернет вещей; способ взаимодействия ІоТ узлов. 